\title{
Experience of adults with cystic fibrosis: a perspective based on social phenomenology
}

\author{
Experiência de adultos com fibrose cística: um olhar da fenomenologia social \\ Experiencia de adultos con fibrosis quística: una mirada de la fenomenología social
}

\section{Samara Macedo Cordeiro', Maria Cristina Pinto de Jesus", Renata Evangelista Tavares', Deise Moura de Oliveira'II, Miriam Aparecida Barbosa Merighi' \\ 'Universidade de São Paulo, Nursing School. São Paulo, São Paulo, Brazil. \\ "Universidade Federal de Juiz de Fora, Nursing School. Juiz de Fora, Minas Gerais, Brazil. \\ "' Universidade Federal de Viçosa. Viçosa, Minas Gerais, Brazil.}

How to cite this article:

Cordeiro SM, Jesus MCP, Tavares RE, Oliveira DM, Merighi MAB. Experience of adults with cystic fibrosis: a perspective based on social phenomenology. Rev. Bras. Enferm. [Internet]. 2018;71(6):2891-8.

DOI: http://dx.doi.org/10.1590/0034-7167-2017-0749

Submission: 10-20-2017

Approval: 08-01-2018

\begin{abstract}
Objective: To understand the experience of adults living with cystic fibrosis. Method: A qualitative study based on the social phenomenology by Alfred Schütz, carried out with 12 adults interviewed in 2016. The statements were analyzed and organized into concrete categories. Results: The following categories were evidenced: "The biopsychosocial impact of the disease on daily life", "Social prejudice as a generator of embarrassment", "Coping strategies" and "Fear, uncertainties and the desire to carry out life projects". Final considerations: The understanding of the experience lived by adults with cystic fibrosis allowed unveiling intersubjective aspects experienced by this public that should be considered by health professionals in the care of this group. It is up to the professionals involved in assisting these people to develop care strategies aimed at completeness, respect for the world of meanings of each individual, their life history, and intersubjectivity that is specially built in the relationship between professionals and people with cystic fibrosis.
\end{abstract}

Descriptors: Cystic Fibrosis; Adult; Emotions; Nursing; Qualitative Research.

\section{RESUMO}

Objetivo: Compreender a experiência de pessoas adultas que convivem com a fibrose cística. Método: Estudo qualitativo fundamentado na fenomenologia social de Alfred Schütz, realizado com 12 adultos entrevistados em 2016. Os depoimentos foram analisados e organizados em categorias concretas. Resultados: Foram evidenciadas as categorias: "O impacto biopsicossocial da doença no cotidiano", "O preconceito social como gerador de constrangimento", "Estratégias de enfrentamento" e "Medo, incertezas e desejo de realizar projetos de vida". Considerações finais: A compreensão da experiência vivida por adultos com fibrose cística possibilitou desvelar aspectos intersubjetivos vivenciados por esse público que devem ser considerados pelos profissionais da saúde no cuidado a esse grupo. Cabe aos profissionais envolvidos na assistência a essas pessoas elaborar estratégias de cuidado que visem à integralidade, ao respeito ao mundo de significações de cada um, à sua história de vida e à intersubjetividade especialmente construída na relação profissional/pessoa com fibrose cística.

Descritores: Fibrose Cística; Adulto; Emoções; Enfermagem; Pesquisa Qualitativa.

\section{RESUMEN}

Objetivo: Comprender la experiencia de personas adultas que conviven con la fibrosis quística. Método: Estudio cualitativo fundamentado en la fenomenología social de Alfred Schütz, realizado con 12 adultos entrevistados en 2016. Los testimonios fueron analizados y organizados en categorías concretas. Resultados: Fueron evidenciadas las categorías: "Impacto biopsicosocial de la enfermedad en el día a día", "Preconcepto social como generador de bochorno", "Estrategias de enfrentamiento" y "Miedo, incertidumbres y deseos de realizar proyectos de vida". Consideraciones finales: La comprensión de la experiencia 
atravesada por adultos con fibrosis quística permitió develar aspectos intersubjetivos experimentados por ese grupo, que deben considerar los profesionales de salud para su cuidado. Corresponde a los profesionales involucrados en la atención de estas personas elaborar estrategias de atención que apunten a la integralidad, el respeto al mundo de significaciones de cada uno, su historia de vida y la intersubjetividad especialmente construida en la relación profesional/persona con fibrosos quística.

Descriptores: Fibrosis Quística; Adulto; Emociones; Enfermería; Investigación Cualitativa.

\section{INTRODUCTION}

Cystic fibrosis (CF) is a chronic, genetic, multisystemic disease most prevalent in populations of European origin. There are more than 30,000 children and adults with CF in the United States. In Brazil, the number of adults with CF is represented by $551(22.3 \%)$ people older than 18 years of age ${ }^{(1)}$.

Clinical manifestations of CF include gastrointestinal conditions, which can manifest as fatty and pale stools, diarrhea, malnutrition, meconium ileus, pancreatic insufficiency, constipation and gastroesophageal reflux. Impairment of the respiratory tract is responsible for the greater morbidity and mortality of people with this disease. It results in productive cough as well as numerous airway infections. Pneumonia is often present ${ }^{(2)}$.

With advances in scientific research, diagnosis and treatment have been instituted earlier, resulting in a significant increase in the survival of people living with CF. This disease is no longer considered potentially fatal in childhood, and life expectancy is currently estimated at 40 years old ${ }^{(3)}$.

Longevity has brought new responsibilities to people living with CF. These are related to professional life, the marriage relationship, children and the responsibility for one's own care. Moreover, in the adult population, the clinical manifestations, mainly the respiratory ones, often become more severe; the pulmonary function is reduced and, consequently, there is an increase in the number of hospitalizations. Comorbidities such as diabetes mellitus, liver disease, depression, and osteoporosis, which are less common in childhood, may also occur ${ }^{(4)}$.

Cystic fibrosis requires an intense routine of daily care that, added to its signs and symptoms, directly impacts the daily life of people affected, especially their quality of life ${ }^{(5)}$, becoming a complex chronic condition that generates biological, psychological and social impacts, despite the advances achieved ${ }^{(6)}$.

Studies addressing the health-related quality of life (HRQoL) of adult people living with CF in the UK and Hungary have shown that the time required for daily treatment is one of the factors that make these people perceive a worsening in their HRQoL ${ }^{(7-8)}$.

Therefore, similar to the study mentioned above, it is important to give voice to the adults who live with $\mathrm{CF}$, and to produce evidence aiming at qualified, individual care, focused on the real needs of this population. The following questions guided this study: How do adults live with CF? Since this is a chronic disease, what are these people's life plans? The objective of this study was to understand the experience of adults living with cystic fibrosis.

The present research can provide support for health professionals, especially nurses, from different points of the healthcare network to assist and coordinate care centered on the singularities of adults living with CF.

\section{OBJECTIVE}

To understand the experience of adults living with cystic fibrosis.

\section{METHOD}

\section{Ethical aspects}

Because this is a study involving human subjects, it was approved by the Research Ethics Committee of the School of Nursing of the University of São Paulo.

Study type and theoretical and methodological framework

This is a qualitative study with an approach focused on the social phenomenology by Alfred Schütz ${ }^{(9)}$. This framework allows the understanding of social phenomena, starting from the intersubjective relationships of human beings in the everyday world. To base the study, the following theoretical assumptions were used: social world, intersubjectivity, biographical situation, collection of knowledge and social action (reasons why and reasons for).

In the social world, which precedes human existence, adults who live with CF share common experiences, feelings, understandings, and interpretations in an intersubjective context. The way these adults place themselves in this world (biographical situation) is related to the collection of knowledge that includes the social relationships established in the daily life, from the life with the disease. In the social world, the action of adults living with CF has meaning and is based on experiences involving relationships with family members, friends and professionals that help in treatment (reasons why). In this context, as these people are reflective actors and producers of meaning, they are capable of projecting changes in their life-world, in an attempt to overcome the restrictions imposed by the disease (reason for).

\section{Study settings}

The starting point to select the participants was the Association of Assistance to Cystic Fibrosis in the State of São Paulo (APAM). It was founded in 1979 and is a non-profit social organization that aims to provide support to people who live with CF and their families. It has approximately 637 registered users, including both adults and children.

\section{Data collection}

The participants were approached in the APAM. Through her participation in ordinary meetings, it was possible to approach 
a user with CF who met the inclusion criteria of the study: to have cystic fibrosis, to be between the ages of 18 and 59 years, regardless of gender, and to live in the city of São Paulo.

Initial contact was made with this user to clarify the purpose of the present research, elucidating the ethical aspects involved, and inviting her to participate in the research. After her agreement, and the phenomenological interview, the participant indicated two new participants who, therefore, indicated other participants that met the inclusion criteria of the study, and so on, until the study sample was formed. This sampling technique is called snowball sampling ${ }^{(10)}$.

Adults with CF were contacted via telephone after the previous indication. In this contact, information about the research and its objectives were provided, and the invitation was formalized for the participation in the study. The interviews were scheduled according to the availability of date and time of each participant. The researcher tried to create a comfortable environment so the statements could take place naturally. In addition to this, the use of the phenomenological interview ${ }^{(11)}$ favored greater proximity to each adult.

Participants were individually approached. An informed consent form was read and signed by all subjects before data collection began. Twelve adults, including men and women, participated in this study. On average, the interviews lasted one hour, were audio-taped, and obtained between February and May 2016. The following questions guided the interview: How do you cope with cystic fibrosis? Considering that you have this chronic illness, what are your life plans? In the script of the interview, sociodemographic and clinical issues were included to favor the characterization of the participants, showing their biographical situation.

The number of interviews was not established a priori. The results were obtained until the content was enough to allow the deepening, comprehensiveness, and diversity of the process of understanding the studied object, in accordance with recommendations for qualitative research ${ }^{(12)}$. Twelve interviews were performed, all of which were considered for analysis. To ensure anonymity, the speeches were identified by the letter A, as in adult, and the Arabic numerals corresponding to the order of the interviews, that is, A1 to A12.

\section{Organization and data analysis}

The organization and analysis of the statements were carried out following steps suggested by researchers of social phenomenology ${ }^{(11)}$. After obtaining each interview, it was transcribed in its entirety. In the sequence, the first readings were carried out, aiming at the comprehension of the interviews as a whole in order to apprehend the global meaning of the experience lived by the participants. In a second moment, new readings were performed, with excerpts of the statements being highlighted to evidence the significant aspects of the experience of living with cystic fibrosis in adult life. The excerpts that presented convergence of meanings were grouped to compose concrete categories. These categories revealed the "reasons why" and "reasons for" that show the typical characteristics of "adult people living with CF", indicating that the concerns were answered, and the proposed goal was achieved. The results of the study were discussed in light of the scientific evidence on the subject, with Alfred Schütz's social phenomenology being the guiding thread.

\section{RESULTS}

Six men and six women, with an average age of 26 years, all with complete elementary education and some with undergraduate and graduate degrees participated in this study. Most of them did not work and lived with their parents. All were single, had no children, had been living with the disease for an average of 20 years. Most patients used more than six daily medications.

After analyzing the statements, the categories that reveal the context of meanings attributed by adults with CF in daily living with the disease emerged (reasons why): "The biopsychosocial impact of the disease on daily life", "Social prejudice as a source of embarrassment", "Coping strategies". The category "Fear, uncertainties and the desire to carry out life projects" represents the expectations of these people (reasons for).

\section{Category 1: The biopsychosocial impact of the disease on daily life}

Participants reported difficulties in living with CF in adult life. They refer fatigue, the impossibility of performing activities of daily living, the need to use multiple medications, and the great time demand to take the treatment. This routine makes it impossible for them to work, finish their studies, do their leisure activities, and often isolate them socially:

It is tiring, a very strong cough. There are lots of inhalations and coupage. [...] I got more tired, I had no mood to go out. My friends called me out and I never went, and I avoided seeing them. Being able to work from home reduces my worries, so I do not have to miss work because of consultations and hospitalizations [...]. (A1)

I was always being admitted to hospital, every year I was in a hospital, four to five times a year [...] I could not go to college and I continued in this routine of staying in hospital a lot, and this disturbs me too much. I cannot work either, and this is very difficult for me. [...] and every time I had to quit my job, it was because my lung was already asking for help, and that makes me sad. Today I have a lung function of $29 \%$, I'm very tired. I get tired when I walk, take a shower and wash the dishes. (A5)

[...] I get really tired to climb stairs. [...] I need many medicines and physical therapy sessions. I have never worked. I was always hospitalized, so it was impossible to work. (A11)

I was breathless, I lived around with inhalation, infection and hospitalization [...] after I started using oxygen, it got much worse. I was stuck at home, I was even too lazy to think about leaving, because the oxygen was heavy, difficult to carry [...] the routine is not easy, because there are eight inhalations a day, and also the physical therapy and medications. (A12)

Category 2: Social prejudice as a source of embarrassment

Adults living with CF report that cough, which is often present, leads the general public, who do not know the disease, to show 
concern and associate cystic fibrosis with contagious and serious diseases, which causes shame and embarrassment to them:

Sometimes I get very embarrassed because I went to places and started coughing, coughing, coughing, and people stared at me in disgust. [...] when I wear a mask, I notice people's eyes at me, especially when people come close to me and ask me why I wear a mask. (A1)

People do not know the disease and then they say: Oh, is this contagious? Is this AIDS? Is it tuberculosis? One day, in the classroom, a teacher watching me coughing too much, said that I could not stay in the room because it was tuberculosis, and it was in front of everybody. I was very embarrassed. (A2)

According to the participants, people (boy/girlfriends, their families) are prejudiced about cystic fibrosis, which prevented them, for example, from telling about the disease and staying in a loving relationship:

I only dated one girl for a long time, but we broke up because her father found out I had CF, and he did not want his daughter to date an ill person. (A2)

It's annoying with the boyfriend, for example, sometimes they keep asking what it is. Sometimes I did not feel comfortable talking or telling about the disease because I was afraid of how they would react. (A4)

\section{Category 3: Coping strategies}

For some adults living with $\mathrm{CF}$, the disease is not the center of their lives. They claim that they try not to live for the illness and the treatment. They are positive, optimistic, resilient and are always searching for strategies to overcome the limitations imposed by the disease:

[...] it's not because I have CF that I get discouraged, I learned to live with it. We cannot give up. It is not because you are sick that you will stop your life and will be thinking that you will die. [...] if CF keeps me from going to parties, that's fine, but that does not stop me from meeting my friends, setting up a barbecue and meeting them [...] another thing, I cannot work on a certain job, but what's wrong? There is not only that job, so I always try to think like this, there is life beyond illness [...] We have to face everything with optimism, pessimism does not help at all. (A1)

I'm fine with life, I do not expect them to feel sorry for me, I'm positive [...] although the disease makes my life difficult I will never let it prevent me from living. I always go out with my friends, I go to the beach, bars, bowling, I am the manager of my life. I live with cystic fibrosis, it's part of my life. (A2)

I have hope, I believe it will be all right, I am very positive. (A5)

And one thing I never did was let the disease take over my life, I wanted to do everything that everyone did. Going out just like everyone else went out, and I never thought, that I'm sick and I cannot. Even when I was feverish I was in the middle of people, I was always like that. I never let sickness be the focus of my life, I always thought the opposite, I am the one who dominates, it is not the disease that dominates my life. (A8)

According to the participants, having the support of family, friends, boy/girlfriend and the professional team represents a support to face the difficulties experienced:

My family helps me a lot. They give me courage, they will not let me give up in difficult times. My friends and my family are my base, they give me a lot of strength. There is always someone who comes to talk to me, who distracts me and this is very important for me [...] the doctors, the nurses, they are also very nice, they saw our family, because we are not patients that go once to hospital, we are always there, and we create a bond and this makes you closer, and this helps a lot to overcome the disease. (A1)

My friends that cheer me up and help me a lot. (A2)

[...] my friends also have CF, with them I can say anything. [...] we can share everything. I know I'm not alone. There are people who understand you $100 \%$. Even if the contact is only by message [...] you have a partner who understands everything you go through. My parents also understand me very well and help me a lot. [...] (A3)

\section{Category 4: Fear, uncertainties and the desire to carry out life projects}

Fear of death is something present in the life of the participants. The worsening symptoms make them fearful. The statements show that living with the losses of friends who have this disease make them reflect on their own death, which causes fear and despair:

It's bad when I see my friends who have cystic fibrosis dying. They die too soon. I'm afraid for myself, to get very bad and to get my turn. To see them going away is horrible. I lost my best friend who had fibrosis. She passed away and I had depression, I thought I would leave too because she left very fast. (A3)

When I am sick, or when I read about the disease or see other patients who are ill, I get scared. [...] because they always told me that patients with CF did not live much, so I never liked to pass through birthdays, I hate getting old [...] I think: Wow! I'm already 30 years old, am I going to die? Even more because I see and read a lot, it is a fear. Will I live long? This sometimes makes me feel bad. (A4)

Participants live with the idea of having to make a transplant since childhood or adolescence, notice their lung function decreasing each day, and the reality of transplantation becoming closer and closer. Fear of undergoing a surgery is also present in the lives of these adults, although most often the transplant represents a chance to survive or an opportunity to improve quality of life:

At age 19 they started talking about the transplant, but it was very far from me, they talked about lung transplantation and I did not think that would happen to me, but at the age of 20 they started to talk seriously, because I was already very short of breath. I was very scared because I did not know what would be of me after the transplant. (A1) 
I noticed my function test was dropping a lot each year, and I've always heard that when it got to $29 \%$, I was going to the transplant list. Then when I got to 32\%, I asked the doctor myself and said that I knew that the transplant list took a long time, and why I was not in that list yet, and I told him that I realized that with each passing year I was more tired. Then she put me on the list. (A5)

When they put me in the transplant line it was a relief because I thought I would have a chance to live because I could not imagine myself living 10 years from now, because I was very sick. I already had a bad function and the doctors thought it would be better to indicate me to the transplant list before I got worse and could not even wait for the waiting list. I was very scared, but I knew I would pass. (A10)

Waiting for the transplant represents anguish. There are moments when they are well, and others where they are in crisis. In these moments, fear of not having time to make a transplant appears as something that frightens them:

I did not like to look at my position in the transplant waiting line, my parents wanted me to look, but I did not want to. (A9)

It's horrible to be waiting, they called me twice for the transplant. Both times did not work out. I was very anxious, I wanted to undergo transplant a lot, but at the same time, I was very scared because I knew it could not work. (A10)

Waiting for the transplant is complicated [...] I think: Oh my Gosh, will I take it until it's time for the transplant"? I do not look at the list much, I think I get more anxious, I get very sad when I look and spend some time and it is in the same position, I think that there is no time, then I become desperate. (A12)

Despite the distress experienced in living with the disease, waiting for the lung transplant, and even faced with the uncertainty of the accomplishment and success of the surgery, participants expect that after lung transplantation they will have autonomy, independence, they will be able to get married, build a family, have children, resume their studies, find a good job and perform the activities that give them pleasure:

To think that after the transplant I can marry, have children, that motivates me a lot. What I want most is to have my autonomy, my independence. I think about going to college. I want to do this transplant soon, because it's hard for you to live tired. I want to have the pleasure of walking without getting tired, of being able to run, of being able to bathe without getting tired. (A5)

I dream of marrying, having children, I want to have my company, I want to work. (A6)

I want to take a Master course, doctorate and become a professor. These dreams drive me. In my personal life, I would like to have a home and a family. (A7)

\section{DISCUSSION}

The experience of living with CF in adulthood includes the biopsychosocial impact of the disease on the daily life of this group, and the prejudice that leads to embarrassment. Faced with the limitations imposed by the disease, people use strategies that help to cope with the difficulties experienced. When reflecting on the future, they refer to feelings such as fear, uncertainty, and the desire to accomplish life projects.

The daily lives of people with CF take place in the cultural and intersubjective context ${ }^{(13)}$, so they interpret their experiences from individual perspectives that are shaped by a social sense, given their social interaction.

Participants reported that they sometimes failed to perform activities of daily living due to fatigue and lack of energy. Fatigue for some represents the inability to perform activities, and for others, a combination of reduced activity, lack of energy, tiredness, weakness, and moodiness. This is a symptom that accompanies CF patients throughout their lives ${ }^{(14)}$.

In a European study involving 61 people with CF in Germany, England, and France, $41 \%$ of the respondents reported fatigue, which had a significant impact on their daily lives ${ }^{(15)}$. Despite the therapeutic advances, CF is still a disease that limits the lives of those who have it and requires a complex and intense therapeutic regimen ${ }^{(16)}$.

Participants also mentioned the difficulty of leaving home and being with friends. That is because almost always they had little energy and enthusiasm for leisure activities, besides the need to transport the oxygen cylinder to all places where they needed to go. Social restriction of people with CF was also addressed in a study carried out with 98 young German, English, and French individuals. It was evidenced that $31 \%$ of the interviewees avoided leaving home and perceived their relationships with their friends were impaired by the presence of the disease ${ }^{(15)}$.

The impact on professional life was also pointed out by the participants of the present study who mentioned the symptoms and treatment of CF as a factor hindering the completion of studies, insertion, and permanence in the labor market. This result was also evidenced in a critical review of the literature that showed that CF distracts people from dedicating to studies, which may compromise the achievement of their full academic potential, jeopardizing their future professional career ${ }^{(17)}$.

In the United Kingdom, an investigation of 45 young adults with CF found that $52 \%$ felt that symptoms, treatment, and frequent hospitalizations had a negative impact on studies and work $^{(18)}$. In Brazil, according to a study conducted by the Brazilian Study Group on Cystic Fibrosis in 2014, of 456 adults, only 79 men and 72 women had a formal job ${ }^{(1)}$.

In addition to the difficulty of attending school, leaving home, entering and staying in the job market, adults find themselves uncomfortable in public places, because intense coughing attracts people's gaze. This behavior makes them believe that because people are not aware of CF, they show pity and fear, because they associate CF with contagious diseases.

The literature demonstrates that CF carries a social stigma with it, considering the fragility imposed by the daily routine of biopsychosocial treatments and limitations ${ }^{(19)}$.

People's prejudice and the fear of talking about the illness keep participants far from loving relationships. A study conducted in the USA with adolescents and young adults diagnosed with CF pointed out that the feeling of being stigmatized is related to 
higher rates of social isolation, financial difficulties, anxiety, and depression ${ }^{(20)}$. Shame causes them to avoid sharing with others the fact that they have the disease ${ }^{(21)}$. Sharing or not sharing about the disease with the social network becomes a decision that is often accompanied by anxiety, stress, and evaluation of the potential harms of this news in their interpersonal relationships ${ }^{(20)}$.

The relevance of the social context in which a human being is inserted is envisioned by Alfred Schütz's social phenomenology as a meaning-producing space. In social reality, we interpret the world around us, meaning and re-signifying our experiences based on the way we are situated in this world and from the wealth of knowledge available to $\mathrm{us}^{(9)}$. This way, the stigma experienced by these adults rests on the differences between what is considered normal and what is deviant, or pathological.

Some strategies are used by adults to live with CF. They say they are positive, optimistic and resilient. An optimistic perception has also been reported in a study conducted in the northern US. Its results showed that optimism appears as a protective factor for emotional functioning, favoring the maintenance of positive perspectives regarding treatment ${ }^{(21)}$. Likewise, accepting the disease optimistically can help to address the challenges of CF in adulthood ${ }^{(18)}$. In addition, to believe in one's own competence and self-efficacy to overcome adversity and be persistent are also determining factors for strengthening the resilience of adults living with $\mathrm{CF}^{(22)}$.

Another form of coping reported by participants was the support from friends and family. Family support was established as an important tool for psychological adaptation to stressful events resulting from therapy. In the statements of some participants, it was noticed that the family generated the necessary psychoemotional support to overcome the moments of tension and discouragement that arose during the course of treatment.

The support of family and friends was also mentioned in studies conducted in Austria and the USA, which evidenced the search for social network support as one of the main strategies used for people coping with $\mathrm{CF}^{(18)}$. Besides promoting self-confidence, reducing fear, encouraging optimism and resourcefulness during treatment ${ }^{(3)}$, having friends and family to share anxieties and fears with resulted in low levels of anxiety and depression, greater compliance to treatment, and better quality of life ${ }^{(22)}$.

The participants in the present study reported establishing a bond with doctors and nurses because of frequent hospital visits. The relevance of the support from health professionals in the promotion of spaces that favor the discussion of the desires of people living with CF was pointed out in the international literature ${ }^{(22-24)}$.

A systematic review of the literature pointed to a significant correlation between professional support and adherence to prescribed treatments. Failures in assistance were related to poor communication, impersonality in the treatment of those assisted, and information that was not very clear and insufficient $^{(23)}$. In a study carried out with children and adults living with CF and their families, in several treatment centers in the USA, it was pointed out that both the patients and their relatives indicated the following as positive aspects of the work of the professionals who assisted them: respect, understandable explanations about the illness, questions answered with attention and sufficient time in the presence of the professional ${ }^{(24)}$.

In the present study, fear and uncertainty about their clinical status in the future, and the loss of their friends with the disease make the adults living with CF reflect about their own finitude and live with the anguish of impending death.

In spite of the increase in CF patients life expectancy, the gradual worsening of the clinical picture indicated by the increasing need for admissions, reduction of antibiotic response, increased loss of lung function, worsening of nutritional status, need for therapeutic use of oxygen, and discussion about lung transplantation causes feelings such as anguish and fear of death ${ }^{(4)}$.

Pulmonary transplantation is a reality discussed since childhood and adolescence by people living with CF. However, with the possibility of effecting this therapeutic resource, they manifest the feeling of fear related to the surgical procedure. In contrast, they report the relief of finally entering the waiting list for the transplant and being able to stay alive and without the limitations imposed by CF.

This ambivalence of feelings was also evidenced in a similar survey conducted in Lausanne, Switzerland. Although the transplant decision was not questioned, and they believed in its success, many feared the unfavorable outcome because they believed that transplantation was a very risky surgery ${ }^{(25)}$.

Despite the challenges experienced in living with $\mathrm{CF}$, and waiting for lung transplantation, the participants elaborate plans for the future that motivate them to continue life. They believe that after the lung transplant surgery, they will have autonomy, independence, will be able to get married, have children, raise a family, continue their studies and find a good job.

In a study conducted in Newcastle, UK ${ }^{(18)}$, the quest for autonomy, independence and hope for a life free from CF difficulties were the main plans for the future of young adults with CF. This was also observed in a study conducted in Australia. People with CF expected to have a future free from the rigid treatment routines and mentioned that, one day, they would be able to travel, work and study, leaving hospital admissions in the past ${ }^{(26)}$.

To form a family and to become parents have been increasingly pointed out as future perspectives of adults living with CF. According to a study conducted in Ghent, Belgium, the desire to have children was present in this population. Of the 46 participants, $43 \%$ said they would like to have biological children, and only $11.1 \%$ indicated adoption as an option ${ }^{(27)}$.

The typical characteristic of the action studied showed that the negative implications of CF in the daily life of adults living with the disease drive them to search for coping strategies, and even in the face of fear and uncertainties of the diagnosis and the possibility of lung transplantation, they try to accomplish their life projects.

\section{Study limitations}

Limitations of this study include the fact that it was carried out with a specific group of adults with CF living in the same space, time and with similar cultural characteristics, which prevents the generalization of the results.

Contributions to the areas of nursing, health and public policies

Regarding adult people living with $\mathrm{CF}$, it is believed that to evidence their demands and needs in face of daily living with the disease favors the re-elaboration and re-dimensioning of attitudes and actions regarding the diagnosis and treatment of this chronic condition. 
The results of the present study meet the purposes of the National Humanization Policy with regard to the development, implementation and, mainly, compliance with strategies of embracement, comprehensiveness, longitudinality, and coordination of the care required when assisting people with chronic diseases, as is the case of CF.

As for health professionals, especially nursing professionals, it is believed that the aforementioned results can support the planning and implementation of care based on the subjective demands of care of this public. In addition, they can provide an improvement to teaching and research in relation to $\mathrm{CF}$, since this is a subject rarely explored in the scope of professional training, especially under the eyes of nurses.

\section{FINAL CONSIDERATIONS}

The understanding of the experience of adults living with CF makes it possible to reveal the intersubjective aspects experienced to be considered by health professionals in the care of this group. The results of this study show the biopsychosocial impact of this chronic disease on the daily life of adults, the difficulties in dealing with the prejudice that arises due to the illness, the coping strategies used to overcome the limitations imposed by the disease, and the life plans projected by this group.

With these elements, the professionals involved in assisting CF patients can develop care strategies aimed at comprehensiveness, respect for the world of meanings of each individual, their life history, and intersubjectivity that is specially built in the relationship between professionals and people with cystic fibrosis. This is considered crucial in this study to give quality to the care of this public.

A suggestion for future studies is the development of strategies that favor humanized care aimed at supporting this group, not only considering the objective issues related to the diagnosis and treatment of $\mathrm{CF}$, but also subjective aspects that permeate the experience of living with CF.

\section{FUNDING}

Coordination for the Improvement of Higher Education Personnel - CAPES.

\section{REFERENCES}

1. The Brazilian Cystic Fibrosis Study Group. Brazilian Cystic Fibrosis Registry Report 2014.[Internet] São Paulo: REBRAFC; 2014 [cited 2017 Sep 14]. Available from: http://portalgbefc.org.br/relatorios-anuais-rebrafc/

2. Nathan K, Shteinberg M, Rivlin J. Cystic fibrosis survival trends in Carmel Medical Center. Harefuah[Internet]. $2015[\mathrm{cited} 2017$ Sep 14];154(6):373-404. Available from: https://www.ncbi.nlm.nih.gov/pubmed/26281081/

3. Kaushansky D, Cox J, Dodson C, McNeeley M, Kumar S, Iverson E. Living a secret: disclosure among adolescents and young adults with chronic illnesses. Chronic Illn[Internet]. 2017[cited 2017 Sep 14];13(1):49-61. Available from: https://www.ncbi.nlm. nih.gov/pubmed/27343016

4. Ronan NJ, Elborn JS, Plant BJ. Current and emerging comorbidities in cystic fibrosis. Press Med[Internet]. 2017 [cited 2017 Sep 14];46(6):125-38. Available from: https://www.ncbi.nlm.nih.gov/pubmed/28554721

5. Quittner AL, Goldbeeck L, Abbott J, Duff A, Lambrecht P, Solé A, et al. Prevalence of depression and anxiety in patients with cystic fibrosis and parent caregivers: results of The International Depression Epidemiological Study across nine countries. Thorax[Internet]. 2014[cited 2017 Sep 14];69(12):1090-7. Available from: https://www.ncbi.nlm.nih.gov/pubmed/25246663

6. Knudsen KB, Pressler T, Mortensen LH, Jarden M, Skov M, Quittner AL, et al. Associations between adherence, depressive symptoms and health-related quality of life in young adults with cystic fibrosis. Springerplus[Internet]. 2016[cited 2017 Sep 14];5(1):1216. Available from: https://www.ncbi.nlm.nih.gov/pubmed/27516954

7. Bradley JM, Blume SW, Balp MM, Honeybourne D, Elborn JS. Quality of life and healthcare utilisation in cystic fibrosis: a multicentre study. Eur Respir J[Internet]. 2013[cited 2017 Sep 14];41(3):571-7. Available from: https://www.ncbi.nlm.nih.gov/pubmed/22835617

8. Bodnar R, Kadar L, Holics K, Ujhelvi R, Kovacs L, Bolbas K, et al. Factors influencing quality of life and disease severity in Hungarian children and young adults with cystic fibrosis. Ital J Pediatr[Internet]. 2014[cited 2017 Sep 14];40:50. Available from: https://www. ncbi.nlm.nih.gov/pubmed/24887479

9. Schutz A, Luckmann T. Las estructuras del mundo de la vida. 2a reimp. Buenos Aires: Amorrortu; 2009.

10. Vinuto J. A amostragem em bola de neve na pesquisa qualitativa: um debate em aberto. Temáticas[Internet] 2014 [cited 2017 Sep 14];22(44):203-20. Available from: https://www.ifch.unicamp.br/ojs/index.php/tematicas/article/view/2144

11. Jesus MCP, Capalbo C, Merighi MAB, Oliveira DM, Tocantins FR, Rodrigues BMRD, et al. The social phenomenology of Alfred Schutz and its contribution for the nursing. Rev Esc Enferm USP[Internet]. 2013[cited 2017 Sep 14];47(3):736-44. Available from: http://www.scielo.br/pdf/reeusp/v47n3/en_0080-6234-reeusp-47-3-00736.pdf

12. Minayo MCS. Amostragem e saturação em pesquisa qualitativa: consensos e controvérsias. Rev Pesqui Qualit[Internet]. 2017[cited 2017 Sep 14];5(7):1-12. Available from: http://rpq.revista.sepq.org.br/index.php/rpq/article/view/82/59

13. Schütz A. Sobre fenomenologia e relações sociais. Petrópolis: Vozes; 2012.

14. Jarad NA, Sequeiros IM, Patel P, Bristow K, Sund Z. Fatigue in cystic fibrosis: a novel prospective study investigating subjective and 
objective factors associated with fatigue. Chron Respir Dis[Internet]. 2012[cited 2017 Sep 14];9(4):241-9. Available from: https:// www.ncbi.nlm.nih.gov/pubmed/23129802

15. Johnson CD, Arbuckle R, Bonner N, Connett G, Dominguez-Munoz E, Levy P, et al. Qualitative assessment of the symptoms and impact of pancreatic exocrine insufficiency (PEI) to Inform the development of a patient-reported outcome (PRO) instrument. Patient[Internet]. 2017[cited 2017 Sept 14];1-14 Available from: https://link.springer.com/content/pdf/10.1007\%2Fs40271-017-0233-0.pdf

16. Macdonald M, Martins-Misener R, Hewig M, Smith LJ, Godfrey CM, Curran J, et al. Experiences of adults with cystic fibrosis in adhering to medication regimens: a qualitative systematic review. JBI Database of Systematic Rev Implement Rep[Internet]. 2016[cited 2017 Sep 14];14(5):258-85. Available from: https://www.ncbi.nlm.nih.gov/pubmed/27532472

17. Hanxhiu A, McKay K, Singh-Grewal D, Fitzgerald DA. Question 10: could the burden of care with cystic fibrosis impact on educational outcomes? Paediatric Resp Reviews[Internet]. 2017[cited 2017 Sep 14];23(1):56-60. Available from: https://www. ncbi.nlm.nih.gov/pubmed/27427312

18. Askew K, Bamford J, Hudson N, Moratelli J, Miller R, Anderson A, et al. Current characteristics, challenges and coping strategies of young people with cystic fibrosis as they transition to adulthood. Clin Med[Internet]. 2017[cited 2017 Sep 14];17(2):121-5. Available from: https://www.ncbi.nlm.nih.gov/pubmed/28365620

19. Pakhale S, Armstrong M, Holly C, Edjoc R, Gaudet E, Aaron S, et al. Assessment of stigma in patients with cystic fibrosis. BMC Pulm Med[Internet]. 2014[cited 2017 Sep 14];1(14):76. Available from: https://www.ncbi.nlm.nih.gov/pubmed/24884812

20. Jamieson N, Fitzgerald D, Singh-Grewal D, Hanson CS, Craig JC, Tong A. Children's experiences of cystic fibrosis: a systematic review of qualitative studies. Pediatrics[Internet]. 2014[cited 2017 Sep 14];133(6):e1683-97. Available from: https://www.ncbi. nlm.nih.gov/pubmed/24843053

21. Oliver KN, Free ML, Bok C, McCoy KS, Lemanek KL, Emery CF. Stigma and optimism in adolescents and young adults with cystic fibrosis. J Cyst Fibros[Internet]. 2014[cited 2017 Sep 14];13(6):737-44. Available from: https://www.ncbi.nlm.nih.gov/pubmed/24795287

22. Mitmansgruber H, Smrekar U, Rabanser B, Beck T, Eder J, Ellemunter H. Psychological resilience and intolerance of uncertainty in coping with cystic fibrosis. J Cyst Fibros[Internet]. 2016[cited 2017 Sep 14];15(5):689-95. Available from: https://www.ncbi. nlm.nih.gov/pubmed/26686827

23. Hanghøj S, Boisen KA. Self-reported barriers to medication adherence among chronically ill adolescents: a systematic review. J Adolesc Health[Internet]. 2014[cited 2017 Sep 14];54(2):121-38. Available from: https://www.ncbi.nlm.nih.gov/pubmed/24182940

24. Homa K, Sabadosa KA, Marrow LC, Marshall BC. Experience of care from the perspective of individuals with cystic fibrosis and families: results from 70 CF Foundation accredited programs in the USA. J Cyst Fibros[Internet]. 2015[cited 2017 Sep 14];14(4):51522. Available from: https://www.ncbi.nlm.nih.gov/pubmed/25649286

25. Brügger A, Aubert JD, Piot-Ziegler C. Emotions while awaiting lung transplantation: a comprehensive qualitative analysis. Health Psychol Open[Internet]. 2014[cited 2017 Sep 14];1(1):1-29. Available from: https://www.ncbi.nlm.nih.gov/pmc/articles/PMC5193305/ pdf/10.1177_2055102914561272.pdf

26. Hogan A, Bonney MA, Brien JA, Karamy R, Aslani P. Factors affecting nebulised medicine adherence in adult patients with cystic fibrosis: a qualitative study. Int J Clin Pharm[Internet]. 2015[cited 2017 Sep 14];37(1):86-93. Available from: https://www.ncbi. nlm.nih.gov/pubmed/25432693

27. Janssens S, Chokoshvilli D, Binst C, Mahieu I, Henneman L, De Paepe A, et al. Attitudes of cystic fibrosis patients and parents toward carrier screening and related reproductive issues. Eur J Hum Genet[Internet]. 2016[cited 2017 Sep 14];24(4):506-12. Available from: https://www.ncbi.nlm.nih.gov/pubmed/26220700 